\title{
KURIKULUM TERSEMBUNYI DALAM PEMBELAJARAN PENDIDIKAN AGAMA ISLAM
}

\section{THE HIDDEN CURRICULUM IN ISLAMIC RELIGIOUS EDUCATION LEARNING}

\section{Caswita}

Sekolah Dasar Negeri 1 Saguling Kecamatan Kawalu Kota Tasikmalaya Jawa Barat

Email: caswitamaulana@gmail.com

Naskah Diterima: 06 Maret 2019; Direvisi: 28 Juli 2019; Disetujui: 30 Juli 2019

\begin{abstract}
The purpose of this study was to examine the curriculum application that integrated between the written curriculum and the hidden curriculum at SD Al-Muttaqin Tasikmalaya. This is qualitative research with a study case approach. The data were collected by interviewing, observing, and analyzing documents conducted at al-Muttaqin elementary school in Tasikmalaya. Secondary sources found out from the books, journals, articles and other scientific works. Based on the research findings, the results of this study indicate that were: (1) the school was giving low attention to the hidden curriculum in PAI's learning whereas the hidden curriculum had a significant effect on the success of PAI's learning. (2) PAI's learning which combines between the written curriculum and the hidden curriculum will produce more applicable and contextual learnings. The findings of this study indicate that was SD al Muttaqin as a private Islamic school has implemented the curriculum that combines between the written curriculum and the hidden curriculum has been implemented well, and it is was producing active learning. This is proven from the achievements of the PAI that always being superior to another school in the city of Tasikmalaya.
\end{abstract}

Keywords: Hidden curriculum; Learning; Islamic religious education

\begin{abstract}
Abstrak
Artikel ini bertujuan untuk mengkaji penerapan kurikulumm yang mengintegrasikan antara kurikulum tertulis (written curriculum) dan kurikulum tersembunyi (hidden curriculum) di SD alMuttaqin Tasikmalaya. Penelitian ini menggunakan pendekatan kualitatif dengan pendekatan studi kasus. Sumber data diperoleh dengan cara wawancara, observasi, dan analisis dokumen yang dilakukan pada sekolah dasar al-Muttaqin di Tasikmalaya. Sumber sekunder berupa buku-buku, jurnal, artikel serta karya ilmiah lainnya. Temuan penelitian ini menunjukkan, pertama sekolah kurang memperhatikan hidden kurikulum dalam pembelajaran PAI padahal hidden kurikulum sangat besar pengaruhnya terhadap keberhasilan pembelajaran PAI. Kedua, pembelajaran PAI yang memadukan antara kurikulum tertulis dan kurikulum tersembunyi akan menghasilkan pembelajaran yang lebih aplikatif dan kontekstual. Temuan penelitian ini menunjukan bahwa SD al Muttaqin sebagai sekolah swasta Islam telah menerapkan kurikulum yang memadukan antara tertulis (written curriculum) dan kurikulum tersembunyi (hidden curriculum) dengan baik, sehingga menghasilkan pembelajaran yang efektif. Hal tersebut terbukti dari prestasi bidang PAI selalau unggul dibanding dengan sekolah lain yang ada di kota Tasikmalaya.
\end{abstract}

Kata Kunci: Kurikulum tersembunyi; Pembelajaran; Pendidikan Agama Islam 


\section{PENDAHULUAN}

Pendidikan formal merupakan bentuk pelimpahan tanggung jawab keluarga dalam bidang pendidikan dan pengetahuan kepada generasi berikutnya. Seperti yang disampaikan oleh Sukmadinata (2007) bahwasanya pendidikan di sekolah diawali karena ketidakmampuan keluarga dalam memberikan pengetahuan dan keterampilan yang lebih tinggi dan mendalam. Beberapa hal yang membedakan sekolah dengan pendidikan informal adalah pertama pendidikan formal memiliki kurikulum tertulis. Kedua dilaksanakan secara formal ada yang mengawasi dan menilai. Ketiga diberikan oleh pendidikan yang memiliki ilmu pengetahuan, bidang pendidikan. Keempat, interaksi pendidikan berlangsung di lingkungan tertentu dengan fasilitas, alat dan aturan tertentu. Sekolah merupakan lembaga pendidikan formal yang secara sistematis melakukan program bimbingan, pengajaran dan latihan dalam rangka membantu siswa untuk mengembangkan potensinya, melalui kurikulum yang telah dirumuskan.

Selama ini guru hanya terpaku pada pedoman kurikulum yang telah ditetapkan oleh pengambil kebijakan (formal kurikulum), dan kurang memanfaatkan faktor lain di luar yang telah ditetapkan (hidden curriculum). Oleh karena itu perlu dilakukan penelitian bagaimana optimalisasi hidden curriculum kurikulum dalam pembelajaran Pendidikan Agama Islam (PAI) di sekolah umum. Penelitian ini penting dilakukan mengingat selama ini penelitian terfokus pada penelitian kurikulum tertulis, sementara faktor lain di luar kurikulum tertulis, yaitu kurikulum tersembunyi kurang diperhatikan.

Identifikasi masalah dalam penelitian ini di antaranya adalah guru PAI terkesan hanya sebatas melaksanakan tugas yang telah ditetapkan. Tidak adanya pendidikan berkelanjutan di luar sekolah. Tidak adanya sinergi serta integrasi dengan guru serta mata pelajaran lain. Guru hanya terfokus pada kurikulum tertulis yang telah ditetapkan. Kurangnya keteladanan dari semua komponen sekolah. Guru PAI kurang memperhatikan kurikulum di luar kurikulum yang tertulis.

Dari berbagai permasalahan yang ada, penelitian ini akan dibatasi satu permasalahan.
Permasalahan yang akan dibahas dalam penelitian ini difokuskan pada yaitu bagaimana pembelajaran PAI di sekolah, yang memadukan kurikulum tertulis dengan hidden curriculum agar menghasilkan pembelajaran yang lebih bermakna dan aplikatif. Selanjutnya dirumuskan masalah dalam bentuk pertanyaan, Bagaimana implementasi kurikulum tersembunyi dalam keberhasilan pembelajaran PAI di sekolah?.

\section{KERANGKA KONSEPTUAL}

Kurikulum merupakan komponen penting dalam sebuah proses pendidikan di lembaga pendidikan. Kurikulum adalah serangkaian rencana program/kegiatan yang harus diselesaikan oleh peserta didik dalam kurun waktu tertentu. Menurut Sukmadinata (2007), ciri utama dari pendidikan sekolah adalah adanya kurikulum. Sehingga secara mutlak kurikulum tidak dapat terpisahkan dengan sekolah. Sementara Klein (1986), menyebutkan bahwa kurikulum memiliki posisi sentral dalam setiap upaya pendidikan. Abdullah (2007) juga mengatakan bahwa kurikulum merupakan komponen terpenting dalam pendidikan dan menyebutnya sebagai jantungnya pendidikan. Senada dengan itu, Hasan (2010), menyatakan bahwa kurikulum memiliki posisi sentral dalam pendidikan, posisi sentral ini menunjukkan bahwa di setiap unit pendidikan, kegiatan kependidikan yang utama adalah proses interaksi akademik antara peserta didik, pendidik, sumber dan lingkungan. Posisi sentral ini menunjukkan pula bahwa setiap interaksi akademik adalah jiwa dari pendidikan. Dapat dikatakan bahwa kegiatan pendidikan atau pengajaran tidak dapat dilakukan tanpa interaksi dan kurikulum adalah desain dari interaksi tersebut. Posisi sesungguhnya kurikulum dalam pendidikan adalah sebagai "the heart of education".

Menurut Sanjaya (2008), kurikulum adalah seluruh kegiatan yang dilakukan siswa baik di sekolah ataupun di luar sekolah, asalkan kegiatan tersebut masih di bawah tanggung jawab sekolah. Para ahli sepakat bahwa pengertian kurikulum modern bukan hanya dokumen rencana pembelajaran, tetapi yang terpenting kurikulum adalah proses pengalaman belajar anak didik. Dalam teori kurikulum sedikitnya ada dua bagian besar kurikulum, 
yaitu kurikulum formal yang tertulis atau written curriculum dan kurikulum yang tidak tertulis yang lebih dikenal dengan hidden curriculum. Untuk mencapai pendidikan yang baik, keduanya harus saling melengkapi dan tidak boleh terjadi ketimpangan. Selain itu, Sanjaya juga membagi kurikulum dengan dua jenis, yaitu pertama kurikulum ideal yang menjadi pedoman guru dan disebut juga dengan kurikulum tertulis. Kedua adalah kurikulum aktual, yaitu operasional kurikulum ideal. Dalam hal ini guru sebagai pelaksana di lapangan, yang menentukan tercapai atau tidaknya tujuan kurikulum ideal. Sehingga sebaik-baiknya kurikulum formal yang telah dibuat oleh para ahli kurikulum, tidak akan mencapai tujuan maksimal apabila dilaksanakan oleh guru yang tidak memahami makna kurikulum tersebut. Sekolah pada prinsipnya didirikan untuk membimbing peserta didik agar dapat berkembang sesuai dengan tujuan yang diharapkan yaitu dapat berperan di tengah masyarakat.

Pendidikan agama Islam sebagai salah satu mata pelajaran di sekolah memiliki tujuan menjadikan peserta didik yang berbudi pekerti, berakhlak mulia. Untuk mewujudkan hal tersebut tidaklah mudah dibutuhkan strategi dan kerja sama berbagai pihak, terutama masyarakat dan orang tua. Selama ini kritik terhadap pendidikan agama Islam terus mengalir semua itu tidak lain dalam rangka perbaikan pendidikan agama Islam. Di antara saran untuk pendidikan agama Islam adalah yang disampaikan Tafsir (1995), bahwa untuk melaksanakan pendidikan agama Islam yang berhasil dibutuhkan keterpaduan. Di antaranya adalah pertama keterpaduan tujuan artinya pencapaian tujuan pendidikan merupakan tanggung jawab semua pemangku stakeholders pendidikan yaitu pemerintah, kepala sekolah, guru, orang tua siswa, dan masyarakat. Kedua keterpaduan materi ialah keterpaduan isi kurikulum yang digunakan atau materi pelajaran. Semua materi pelajaran yang dipelajari siswa hendaknya saling memiliki keterkaitan antara satu mata pelajaran dengan mata pelajaran yang lainnya. Pengikat keterpaduan tersebut adalah tujuan pendidikan keimanan dan ketakwaan. Jadi selain tujuan mata pelajaran itu sendiri, hendaknya semua bahan ajar mengarah kepada terbentuknya manusia beriman dan bertakwa. Ketiga, keterpaduan proses, berarti para pendidik hendaknya menyadari bahwa semua kegiatan pendidikan sekurang-kurangnya tidak berlawanan dengan tujuan pendidikan keimanan dan ketakwaan, bahkan dikehendaki semua kegiatan pendidikan membantu tercapainya siswa yang beriman dan bertakwa.

Dalam mewujudkan tujuan pendidikan Islam dibutuhkan keterpaduan dalam pelaksanaan pembelajaran yaitu keterpaduan antara kurikulum formal yang tertulis dengan kurikulum tersembunyi (hidden curriculum). Sementara itu salah satu tujuan dari pendidikan agama Islam adalah menjadikan peserta didik yang berbudi pekerti, berakhlak mulia. Untuk mencapai tujuan pendidikan agama Islam, terutama yang berkaitan dengan aspek afektif dan psikomotorik, para ahli menganjurkan beberapa cara yang harus dilakukan oleh guru PAI. Cara tersebut di antaranya dengan memberikan keteladanan oleh para guru, pembiasaan sejak usia dini, menciptakan suasana kondusif yang islami, semua guru menjadi guru agama. Selanjutnya untuk optimalisasi pembelajaran pendidikan agama Islam adalah dengan mengoptimalkan fungsi hidden curriculum, kurikulum yang tersembunyi yang tidak tertulis tetapi dapat memberikan pengaruh besar terhadap tercapainya tujuan pendidikan Islam. Hidden curriculum di sekolah secara konkret meliputi, perilaku guru disekolah, pola komunikasi antar komponen sekolah termasuk dengan peserta didik, aturan tata tertib di sekolah, kode etik guru, penerapan hukuman yang mendidik dan konsisten, lingkungan serta suasana sekolah. Faktor-faktor tersebut sangat berdampak sekali bagi penanaman nilai-nilai keislaman bagi anak

Hal tersebut ditegaskan oleh Rosyada (2004) yang mengatakan bahwa kurikulum ideal adalah yang mengintegrasikan antara kurikulum tertulis untuk dipelajari dengan hidden curriculum yang mendukung perkembangan sikap dan kebiasaan-kebiasaan siswa. Hidden curriculum merupakan kurikulum yang tidak sebatas di dalam kelas tetapi semua aktivitas di luar yang masih dalam pengawasan sekolah. Semuanya akan sangat berpengaruh sekali terhadap pencapaian tujuan pendidikan Islam. Hidden curriculum meliputi 
pola hubungan komunikasi antara guru dengan siswa, antara kepala sekolah dengan siswa, serta pola interaksi antara komunitas sekolah. Selain itu penciptaan suasana kondusif juga merupakan bagian dari hidden curriculum. Sehingga kebijakan kepala sekolah dalam mengelola sekolah sangat berpengaruh terhadap proses pendidikan. Kebijakan tersebut meliputi tata tertib sekolah, tata tertib bagi guru, pengadaan alat peraga serta laboratorium, serta fasilitas lainnya. Lebih lanjut ditegaskan oleh Noor (2012), ada beberapa fungsi hidden curriculum, yaitu pertama hidden curriculum adalah alat dan metode untuk menambah khazanah pengetahuan anak didik di luar materi, yang tidak termasuk dalam silabus. Misalnya budi pekerti, sopan santun dan apresiatif terhadap lingkungan. Kedua adalah hidden curriculum berfungsi sebagai pencairan suasana, menciptakan minat dan penghargaan terhadap guru jika disampaikan dengan gaya tutur serta keanekaragaman pengetahuan guru.

\section{Penelitian tentang kurikulum} pendidikan Islam di sekolah telah banyak dilakukan dengan tema kajian yang bervariasi. Di antaranya, pertama penelitian dari Haryanto (2010) yang menyatakan bahwa pembelajaran PAI harus dilaksanakan secara integratif dengan pelajaran lain, karena kurikulum yang terpilahpilah dalam sub-sub mata pelajaran akan berdampak pada pengetahuan siswa yang tidak komprehensif. Kedua, penelitian dari Masykuri (2008) diman penelitian ini membahas bagaimana kurikulum PAI dapat mengoptimalkan peranan akal peserta didik sehingga menghasilkan peserta didik yang mampu berpikir kritis dan kreatif. Penelitian tersebut menawarkan model kurikulum dan pembelajaran inkuiri, model ini dapat merangsang kreativitas pada siswa, memberikan kebebasan menyusun pertanyaan dan mengemukakan pendapat secara lisan atau verbal, menimbulkan komunikasi dan kerja sama. Selain itu penelitian tersebut juga mengajukan kritik terhadap kurikulum PAI saat ini, dengan memberikan solusi agar kurikulum PAI disederhanakan dan siswa diberikan kesempatan yang lebih banyak untuk memahami, mendalami serta mengamalkan dalam kehidupan sehari-hari.
Selanjutnya penelitian ketiga yang relevan dengan tema kurikulum PAI di sekolah adalah penelitian Fauzi (2008), fokus terhadap kajian kurikulum pendidikan Islam SMA tahun 2004, dengan mengkritisi beberapa kekurangannya. Penelitian ini menghasilkan kesimpulan bahwa kurikulum pendidikan agama Islam SMA 2004 tidak dibangun dengan berlandaskan filsafat pendidikan Islam yang holistik. Tesis ini juga menunjukkan kecenderungan filsafat barat dalam bangunan kurikulum tersebut.

Keempat penelitian Ruhadi (2011) yang menunjukkan bahwa pengembangan kurikulum di SDIT Assalamah dapat diketahui dari dua hal, yaitu desain pengembangan kurikulumnya yang memadukan antara kurikulum Departemen Pendidikan Nasional dengan kurikulum Departemen Agama, dan penerapan kurikulum yang mengakomodasi desain kurikulum yang telah diterapkan yaitu dengan menerapkan sistem Full Day School dan model pembelajaran berbasis Multiple Intelegence. Dengan desain kurikulum terpadu dan pengembangan kurikulum yang baik akan berdampak bagi perkembangan institusi pendidikan, yaitu kualitas pendidikan semakin meningkat, mampu meraih berbagai prestasi, dan bertambahnya kepercayaan masyarakat terhadap pihak sekolah

\section{METODOLOGI}

Penelitian ini menggunakan pendekatan kualitatif dengan pendekatan studi kasus. Adapun teknik pengumpulan data menggunakan observasi partisipatif, studi dokumentasi, dan wawancara. Observasi partisipatif yaitu peneliti mengamati apa yang dikerjakan obyek penelitian dalam hal ini guru dan peserta didik. Observasi dilaksana-kan melalui beberapa tahapan, di antaranya adalah observasi awal, dilaksanakan sebelum penelitian dilaksanakan. Dilakukan dengan pengamatan yang dilaksanakan di lokasi penelitian. Studi dokumentasi dilakukan pada saat sebelum dan saat pelaksanaan penelitian, seperti pada saat wawancara dengan para narasumber dan pelaksanaan obsesrvasi di kelas. Wawancara dilakukan terhadap narasumber yang berkompeten untuk menjawab permasalahan dalam penelitian ini. 
Pendekatan studi kasus sebagai salah satu jenis pendekatan deskriptif, penelitian yang dilakukan secara intensif, terperinci, dan mendalam terhadap suatu organisme (individu), lembaga atau gejala tertentu dengan daerah atau subjek yang sempit. Dipilihnya pendekatan studi kasus karena dalam penelitian ini obyek yang diamati adalah suatu kasus yang unik yang memiliki keistimewaan sendiri. Keunikan tersebut terletak pada pengembangan kuriklum tersembunyi pada penyelenggraan pendidikan agama Islam di SDN al Muattaqin. Peneliti langsung terjun ke objek penelitian, kemudian melakukan komunikasi dengan kepala sekolah guru dan siswa. Semua itu untuk mendapatkan data-data secara keseluruhan baik lisan maupun tulisan.

Penelitian kualitatif mengeksplorasi sikap, perilaku dan pengalaman melalui wawancara. Sedangkan jenis pendekatan studi kasus dalam penelitian kualitatif adalah pendekatan yang digunakan untuk menyelidiki dan memahami sebuah kejadian atau masalah yang telah terjadi dengan mengumpulkan berbagai macam informasi yang kemudian diolah untuk mendapatkan sebuah solusi agar masalah yang diungkap dapat terselesaikan. (Sugiyono, 2014). Sedangkan yang membedakan pendekatan studi kasus dengan jenis pendekatan penelitian kualitatif yang lain terdapat pada kedalaman analisisnya pada sebuah kasus tertentu yang lebih spesifik. Sementara itu studi kasus yang digunakan adalah studi kasus instrumental (instrumental case study), yaitu studi kasus yang dilakukan dengan meneliti kasus untuk memberikan pemahaman mendalam atau menjelaskan kembali suatu proses generalisasi. Dengan kata lain, kasus diposisikan sebagai sarana (instrumen) untuk menunjukkan penjelasan yang mendalam dan pemahaman tentang sesuatu yang lain dari yang biasa dijelaskan. Melalui kasus yang ditelitinya, peneliti bermaksud untuk menunjukkan adanya sesuatu yang khas yang dapat dipelajari dari suatu kasus tersebut, yang berbeda dari penjelasan yang diperoleh dari obyek-obyek lainnya (Creswell: 2010). Analisis dan triangulasi data digunakan untuk menguji keabsahan data dan menemukan kebenaran objektif sesungguhnya. Metode ini sangat tepat untuk menganalisis kejadian tertentu di suatu tempat tertentu dan waktu yang tertentu pula. Penelitian ini dilakukan di sebuah sekolah dasar Al Mutaqin di Tasikmalaya dengan melihat bagaimana pelaksanaan kurikulum dan pembelajaran PAI dan kesesuaiannya antara kurikulum tertulis dengan yang tidak tertulis. Sumber data utama atau data primer dalam penelitian ini adalah hasil wawancara dari semua komponen sekolah, baik kepala sekolah, guru, tenaga administrasi serta siswa, melihat dokumen kurikulum sekolah, serta observasi pembelajaran PAI di sekolah tersebut.

\section{HASIL DAN PEMBAHASAN}

\section{Pengembangan Hidden Curriculum di SD Al Muttaqin}

Menurut Murni (2012) pelaksanaan hidden curriculum dalam KTSP dilaksanakan dengan cara pengembangan diri. Dalam pelaksanaan pengembangan diri dilaksanakan dengan dua cara yaitu pertama pengembangan diri dengan rencana yang terprogram dilaksanakan dalam kurun waktu tertentu dalam rangka memenuhi kebutuhan siswa secara individual ataupun kelompok. Kegiatan ini berupa layanan bimbingan konseling dan kegiatan ekstra kurikuler. Kedua kegiatan yang tidak direncanakan secara khusus tetapi berdampak besar dalam pencapaian tujuan pendidikan. Kegiatan ini meliputi pertama kegiatan rutin yang sehari-hari dilaksanakan seperti upacara bendera, senam pagi, ibadah secara bersama-sama, disiplin, pemeliharaan kebersihan, dan kesehatan diri sendiri. Kedua yaitu kegiatan spontan misalnya ketika bertemu dengan orang lain mengucapkan salam, tertib dalam antrean dan cara mengatasi masalah. Ketiga yaitu keteladanan dalam perilaku seharihari misalnya berkata dengan bahasa yang baik, berpakaian rapi, rajin membaca, datang tepat waktu, memberikan pujian kepada yang lai

SD Al Muttaqin sebagai sekolah Islam yang menekankan pada aspek akhlak siswa mengembangkan beberapa kegiatan hidden curriculum yang sangat mendukung tercapainya tujuan pendidikan Islam, yaitu dengan beberapa kegiatan. SD Al Muttaqin menerapkan model hidden curriculum melalui 
kegiatan pengembangan diri dan ekstra kurikuler.

\section{Kegiatan Ekstra Kurikuler dan Pengembangan Diri di SD Al Muttaqin}

Ekstrakurikuler merupakan kegiatan untuk mengembangkan bakat, minat, siswa secara optimal yang dapat menjadi bekal siswa di kehidupannya kelak. Ekstrakurikuler merupakan sarana pembelajaran dari apa-apa yang tidak diajarkan di dalam kegiatan intrakurikuler. Selain itu ekstrakurikuler menurut Lickona merupakan sarana efektif untuk membantu siswa mengembangkan rasa dihargai sebagai manusia yang berharga di komunitas sekolahnya (Lickona, 2012). Selain itu menurut M. Mukhlis Fahruddin (2012) ekstrakurikuler merupakan sarana untuk melatih siswa agar memiliki respons refleks dengan baik dalam memecahkan setiap masalah yang mereka hadapi, hal ini butuh latihan dan pembiasaan dalam pengawalan guru dan orang tua. Selanjutnya dikatakan Fakhrudin harapan dari kegiatan ekstrakurikuler adalah anak mempunyai kecerdasan sosial, moralitas, arif dan bijaksana dalam menghadapi dan memecahkan problem yang mereka hadapi, bahkan problem yang dihadapi bangsa ini.

Dalam mencapai keberhasilan pembelajaran PAI dalam prosesnya sangat membutuhkan sekali kegiatan ekstrakurikuler. Karena pembelajaran PAI banyak sekali menekankan aspek afektif serta psikomotorik, sehingga kegiatan ekstrakurikuler sangat penting sekali sebagai sarana penerapan dari apa yang telah diajarkan di dalam kelas. Selain itu pembelajaran PAI yang hanya diberikan porsi sekitar 2-3 jam pelajaran tentunya akan kekurangan waktu sehingga kegiatan ekstrakurikuler merupakan solusi alternatif dari kekurangan jam pelajaran tersebut. Seperti yang dikatakan oleh Haedari (2012) bahwa kekuatan pendidikan agama Islam bukan terletak pada kegiatan formalnya, tetapi banyak pendidikan agama Islam banyak didapat dari kegiatan informal. Oleh karena itu menurut Haedari kegiatan ekstrakurikuler harus dikelola dan dikembangkan secara maksimal.

Ekstrakurikuler merupakan sarana pengembangan bakat dan penyaluran minat peserta didik, oleh karena itu sekolah yang baik harus memfasilitasi berbagai jenis kegiatan yang menjadi minat siswa. Selain itu kegiatan ekstrakurikuler juga merupakan sarana efektif dalam pembentukan karakter siswa, karena di dalam kegiatan tersebut siswa akan belajar mandiri, bertanggung jawab, memiliki jiwa pemimpin, berani, percaya diri dan nilai-nilai kejujuran. SD Al Muttaqin sebagai sekolah Islam terpadu melaksanakan kegiatan ekstrakurikuler sebagai sarana pembentukan akhlak siswa. Kegiatan tersebut yang mendukung pembelajaran pendidikan agama Islam diantaranya sebagai berikut.

Pertama melaksanakan kegiatan malam bimbingan iman dan takwa. Kegiatan ini merupakan kegiatan rutin yang dilaksanakan setiap akhir semester. Kegiatan ini bertujuan untuk meningkatkan keimanan dan ketakwaan siswa. Pelaksanaan kegiatan diwajibkan bagi siswa kelas 4, 5 dan 6, biasanya dilaksanakan pada akhir semester. Dalam pelaksanaannya kegiatan dilaksanakan di dalam lingkungan sekolah dan di luar sekolah yaitu di alam terbuka, diisi dengan bimbingan zikir dan doa agar siswa lebih dekat lagi kepada Allah Swt. Tujuan dari kegiatan ini agar siswa selalu dekat dan mengingat Allah di mana pun dan kapan pun, selain itu siswa diajak untuk mempelajari berbagai ciptaan Allah Swt berupa alam semesta serta isinya. Selain dalam rangka meningkatkan iman dan takwa kegiatan ini juga merupakan sebagai alternatif refreshing setelah siswa melaksanakan ujian akhir semester.

Kedua, kegiatan pengumpulan infak sedekah. Kegiatan ini dilaksanakan setiap hari Jumat pada setiap minggunya, merupakan sarana pendidikan untuk mengajarkan pada siswa agar rela dengan ikhlas memberikan sebagian yang dimiliknya untuk disumbangkan kepada yang membutuhkan. Sejak dini siswa diajarkan serta diberi pemahaman bahwa dari rezeki atau harta yang kita miliki ada sebagian hak orang lain. Untuk selanjutnya langsung dipraktikkan dengan memberikan infak ke sekolah. Dengan pembiasaan sejak dini siswa diharapkan terbiasa membantu orang lain dan tidak sungkan memberikan sebagai uangnya untuk yang membutuhkan sehingga ketika sudah dewasa menjadi orang yang dermawan.

Ketiga, kegiatan penyantunan kaum duafa. Kegiatan ini dilaksanakan secara rutin setelah melaksanakan ujian akhir semester. 
Tujuannya untuk mengajak siswa meningkatkan rasa empati terhadap kaum duafa. Siswa diajak terjun langsung ke pedesaan untuk melihat kondisi riil keseharian masyarakat duafa. Untuk selanjutnya siswa memberikan bantuan secara langsung kepada orang yang membutuhkan. Sekolah memfasilitasi dengan mengumpulkan dana dari siswa, dengan sebelumnya terlebih dahulu diumumkan bahwa anak-anak dianjurkan untuk memberikan sumbangan dengan ikhlas untuk disumbangkan didaerah tertentu. Kegiatan ini sangat baik sekali untuk membentuk karakter siswa, agar lebih peka lagi terhadap masalah di sekelilingnya. Saat budaya hedonisme sudah masuk ke seluruh lapisan masyarakat, baik di pedesaan ataupun di perkotaan. Kota Tasikmalaya sebagai kota kecil yang sedang tumbuh dan berkembang juga mulai terjangkit budaya hedonisme dan individualis. Kegiatan ini diharapkan dapat membentuk siswa menjadi orang yang selalu rendah diri, peka terhadap sesama untuk selanjutnya melakukan aksi untuk meringankan bebannya.

Keempat, kegiatan creative day, sebagai sarana mengekspresikan berbagai kemampuan, bakat dan minat siswa. Kegiatan ini dilaksanakan setelah selesai ujian akhir semester, pada saat minggu tenang menjelang pembagian buku rapor. Kegiatan creative day adalah sarana unjuk kemampuan siswa terutama dalam bidang keagamaan, misalnya pidato bahasa arab, puisi bahasa arab cerdas cermat, Imla, permainan kata, dan Hifzil Quran.

Kegiatan creative day pada setiap pelaksanaannya mengambil tema yang telah ditentukan misalnya untuk tema tahun 2012 adalah "Gemar Berbahasa Arab". Sedangkan tahun sebelumnya mengambil tema "gemar memakan ikan", tema terebut diambil karena adanya pihak sposnsor yang mempromosikan gemar makan ikan. Selain tujuan utamanya adalah untuk mengembangkan kemampuan, bakat, minat siswa dan sebagai sarana untuk mengekspresikannya, juga terdapat hidden curriculum di dalamnya yang mendukung pembelajaran siswa. Hidden curriculum yang diharapkan dari kegiatan ini adalah pertama agar siswa pada saat minggu tenang tidak bermain dengan sia-sia tanpa arahan dan bimbingan yang mendidik atau bahkan tidak masuk sekolah. Kedua kegiatan ini juga merupakan sarana refreshing siswa setelah melaksanakan ujian akhir untuk menghilangkan kejenuhan. Ketiga kegiatan ini juga secara tidak langsung mendidik siswa untuk memanfaatkan waktu yang kosong dengan kegiatan-kegiatan yang positif.

\section{Kegiatan Rutin sebagai Hidden Curriculum di SD Al Muttaqin}

Hidden curriculum selanjutnya yang dikembangkan di SD Al Muttaqin adalah melalui kegiatan rutinitas, spontanitas serta yang terintegrasi dengan kegiatan kokurikuler. Kegiatan pengembangan diri di antaranya dengan menciptakan kondusif suasana sekolah. Setiap pagi hari ketika akan masuk sekolah beberapa guru menyambut kedatangan siswa dengan penuh kasih sayang digerbang kedua. Secara terjadwal guru piket akan selalu menyambut dengan penuh kehangatan datangnya para siswa. Menurut Kepala Sekolah Engkos Kosasih hal itu dilakukan agar para siswa yang datang merasa nyaman dan kedatangannya di pagi hari penuh keceriaan bukan kecemasan dalam menghadapi pelajaran.

Penciptaan perasaan nyaman bagi siswa sangat penting dilakukan agar siswa dalam belajar tidak merasa terbebani. Program ini terlihat tidak terlalu penting dalam proses pembelajaran tetapi dampaknya begitu besar terhadap kondisi psikologis siswa. Dengan penyambutan yang akrab oleh para guru, siswa akan mengawali harunya penuh dengan keceriaan. Suasana sekolah tidak terlihat seram atau tegang karena keberadaan para guru atau staf sekolah yang hilir mudik penuh kesibukan dengan wajah tegang di pagi hari. Seperti yang dikatakan Zamroni (2003) bahwa kultur sekolah selama ini dipercaya sebagai dasar dalam memahami dan memecahkan berbagai persoalan yang muncul di sekolah. Oleh karena itu betapa pentingnya sekolah menciptakan iklim kondusif bagi semua komunitas sekolah. Sementara itu menurut Sudharto (2012) dengan menganalisis beberapa hasil penelitian mengatakan bahwa iklim sekolah yang kondusif sangat berpengaruh terhadap prestasi serta motivasi belajar siswa, setidaknya terhadap beberapa hal di antaranya, yaitu prestasi dan motivasi siswa untuk berprestasi, sikap dan 
motivasi kerja guru, dan produktivitas dan kepuasan kerja guru.

SD Al Muttaqin berusaha menciptakan iklim sekolah yang dapat memotivasi siswa untuk terus mengembangkan bakatnya. Dalam pelaksanaannya tidak mudah dalam menciptakan kondisi sekolah yang kondusif karena memerlukan kesabaran, ketelatenan serta disiplin yang tinggi namun semua itu akan dapat dilaksanakan apabila komunitas sekolah dapat bekerja sama dengan baik. Seperti yang dikatakan Koesoema (2012) bahwa usaha untuk menumbuhkan karakter di sekolah, dapat dilakukan antara lain dengan melalui keteladanan orang dewasa, tata tertib sekolah, manajemen pengelolaan, penerapan peraturan dan disiplin, isi kurikulum, standar akademik yang tinggi, perilaku dalam kegiatan ekstrakurikuler dan keterlibatan orang tua.

Pendapat tersebut dikuatkan oleh Hidayat (2012) bahwa yang paling berat dalam membangun sekolah adalah menciptakan kultur sekolah karena selain membutuhkan dana yang besar juga membutuhkan kesabaran, daya tahan, keuletan, persistensi, dan konsistensi dari seluruh pemangku kepentingan di sekolah yaitu kepala sekolah, guru, orang tua, masyarakat, dan pemerintah. Lebih lanjut Hidayat menganalogikan akan pentingnya kultur sekolah dengan menanam benih tanaman. Apabila akan menanam pohon kurma yang benihnya diambil dari tanah Arab, maka perlu menganalisis dan mengondisikan tanah serta cuaca yang cocok sebelum benih kurma ditanam di Indonesia.

Begitu juga halnya anak dalam dunia pendidikan, anak yang memiliki bakat hebat, tapi karena kondisi sekolahnya tidak mendukung, maka tidak bisa tumbuh optimal, bakatnya akan terpendam, bahkan mati. Sebaliknya, anak yang kepintaran dan bakatnya sedang-sedang saja, tapi karena lingkungan sekolahnya bagus, maka akan tumbuh sebagai anak yang mandiri dan sukses (Hidayat, 2012). Berdasarkan asumsi tersebut maka para ahli sepakat bahwa kultur sekolah peranannya sangat penting sekali dalam proses pendidikan. Sementara itu menurut Lickona (2012) sekolah harus menciptakan enam elemen budaya moral positif di sekolah, yaitu kepemimpinan sekolah, kedua disiplin sekolah, mengembangkan rasa komunitas seluruh sekolah, pengelolaan sekolah yang demokratis, menciptakan komunitas yang baik di antara para orang dewasa, dan memberikan banyak waktu untuk peduli terhadap moral.

Untuk mewujudkan kultur sekolah yang kondusif untuk proses pendidikan SD Al Muttaqin menerapkan tata tertib sekolah. Tata tertib sekolah sangat penting untuk ditegakkan karena dengan penegakan tata tertib tersebut, maka kedisiplinan serta suasana kondusif akan terwujud. Sebagai upaya untuk mewujudkan sekolah yang kondusif SD Al Muttaqin menerapkan tata tertib siswa yang harus ditaati sebagai bentuk pembelajaran. Tata tertib yang diterapkan meliputi aturan umum yang meliputi kewajiban memakai seragam, bersikap sopan pada guru dan teman serta ikut menjaga fasilitas sekolah. Sedangkan kewajiban khusus siswa meliputi peraturan tentang masuk sekolah, aturan di dalam kelas, aturan ketika istirahat, ketika di perpustakaan, ketika di hall, aturan di masjid, aturan di kantin, aturan masuk kantor, aturan di kamar mandi, ketika berada di kendaraan jemputan dan ketika pulang sekolah.

Selain memuat kewajiban-kewajiban siswa dalam tata tertib juga di atur hak-hak siswa. Diantaranya mendapatkan pendidikan dan pengajaran yang sama, mendapatkan perlakuan yang sama sesuai tata tertib serta berhak menggunakan fasilitas sekolah. Dalam tata tertib juga terdapat larangan bagi siswa serta sangsi yang diberikan apabila siswa melanggar larangan tersebut, yang meliputi bentuk sangsi serta pemberian sangsi. Yang terpenting dari semua tata tertib tersebut adalah bagaimana penegakannya dengan adil dan bijaksana, sebagai pembelajaran hidden curriculum akan keadilan dan kesamaan dimata hukum bagi setiap siswa. Sebagaimana yang dikatakan oleh Noor (2012) bahwa tata tertib sekolah yang dibangun secara demokratis akan mengajarkan kepada siswa bagaimana cara berdemokrasi dalam kehidupan nyata. Hasilnya diharapkan siswa memiliki pengalaman aturan main dalam kehidupan masyarakat.

Program selanjutnya yang dilakukan di SD Al Muttaqin untuk menciptakan kultur kondusif adalah menciptakan lingkungan sekolah dengan membuat hiasan yang ditempel di dinding sekolah. Hiasan tersebut berupa 
hiasan-hiasan islami, dengan kata-kata mutiara serta berbagai kaligrafi Islam. Semua itu dilakukan agar siswa yang berada di lingkungan sekolah dapat selalu mengingat berbagai katakata mutiara, serta setiap hari membaca beberapa ayat Alquran yang terpajang di dinding sekolah. Selain dengan gambar berupa ayat-ayat Alquran, setiap pagi hari siswa juga diperdengarkan ayat-ayat Alquran setiap pagi sebelum pelajaran sekolah dimulai. Hal ini penting dilakukan agar siswa akan belajar dengan melihat dan mendengar.

Dengan demikian siswa akan selalu akrab dengan ayat-ayat Alquran yang pada akhirnya menjadi hafal dengan tidak disadari dan direncanakan, inilah yang sebenarnya yang menjadi tujuan dari hidden curriculum. Anak belajar dari hal-hal yang tidak direncanakan bahkan tidak dianggap penting padahal hal itu sangat besar pengaruhnya terhadap pendidikan. Pembiasaan rutin selanjutnya yaitu semua komponen sekolah wajib mengucapkan salam kepada setiap orang yang ditemuinya pada saat berada di lingkungan sekolah. Ucapan salam yang diucapkan adalah salam yang sesuai dengan ajaran Islam. Setiap siswa harus dibiasakan akan pentingnya salam diucapkan kepada sesama muslim, selain itu siswa juga harus diberi penjelasan akan makna dari salam itu sendiri. Siswa juga diajarkan tata cara mengucapkan salam dan hukumnya mengucapkan dan menjawab salam.

\section{Integrasi Hidden dan Written Curriculum PAI di SD AI Muttaqin}

Menurut Sanjaya (2010) pelaksanaan hidden curriculum harus sejalan dengan kegiatan kurikulum. Selain itu dikatakan juga bahwa hidden curriculum harus mendukung kegiatan kurikulum. Hidden curriculum tidak boleh berjalan sendiri, apalagi bertentangan dengan kurikulum resmi. Pelaksanaan pembelajaran PAI di SD Al Muttaqin berusaha untuk memadukan antara hidden curriculum dengan kurikulum resmi. Kegiatan yang dimaksud adalah bagaimana guru memadukan berbagai materi pembelajaran dengan pesanpesan moral. Ada beberapa faktor yang menjadi penentu keberhasilan hidden curriculum dalam pembelajaran.
Sebagai sekolah Islam terpadu yang mengutamakan pembentukan akhlak siswa, peranan guru sangat dominan dan menentukan keberhasilannya. Oleh karena itu SD Al Muttaqin sangat menyadari betapa pentingnya mutu guru. Guru merupakan unsur yang paling penting bagi pengembangan hidden curriculum, karena segala apa yang diucapkan guru dan diperbuat akan menjadi model bagi siswa yang lama kelamaan akan dicontoh. Sehingga dapat dikatakan guru adalah tumpuan pendidikan bagi siswanya. Seperti yang dikatakan Rohinah (2012) bahwa tugas dan tanggung jawab guru di sekolah ataupun di luar sekolah sangat kental dengan pesan-pesan moral kebaikan. Sehingga dapat dikatakan ketika guru mengajar di kelas, berarti sama dengan menyampaikan pesanpesan tuhan berupa kebajikan-kebajikan kepada siswa.

Segala apa yang diucapkan dan dilakukan oleh guru merupakan hidden curriculum bagi siswanya, yang banyak berpengaruh terhadap perilaku anak. Setiap apa yang dilakukan oleh guru akan mudah diikuti siswa baik itu hal yang positif ataupun negatif. Oleh karena itu ketika berada dilingkungan sekolah, guru tidak boleh melakukan hal-hal yang dapat berdampak buruk bagi perilaku siswa. Misalnya merokok dilingkungan sekolah, membuang sampah tidak pada tempatnya atau berkata dengan perkataan yang tidak sopan.

Sementara itu menurut Indriyanto (2012) dikatakan bahwa guru dalam mengajar memiliki dua fungsi yaitu mengajar dalam arti transferring dan transforming. Mengajar dalam arti transferring yaitu memindahkan informasi yang disebut ilmu pengetahuan kepada para siswa yang diajarnya, sedangkan mengajar dalam arti transforming yaitu menanamkan nilai budaya positif kepada para siswa yang diajarnya. Dalam menjalankan peran kedua, guru tidak hanya mengajarkan tetapi sekaligus menjadi suri teladan bagi siswanya. Kedua fungsi tersebut tidak bisa dibandingkan mana yang lebih penting, Keduanya mempunyai peran yang setara karena membentuk keseimbangan antara kompetensi nalar dan kompetensi kepribadian bagi para siswa. Keduanya terangkum dalam hasil pendidikan 
yang sekarang ini menjadi topik pembicaraan yaitu siswa berkarakter.

Dalam rangka menyiapkan guru yang bermutu SD Al Muttaqin melakukannya sejak mulai proses rekrutmen. Guru yang mengajar di SD Al Muttaqin diseleksi oleh pihak yayasan penyelenggara pendidikan. Syarat yang paling utama adalah semua guru harus bisa membaca Alquran dengan baik dan benar selain itu bagi calon guru diutamakan pernah menjadi aktivis organisasi mahasiswa, sosial masyarakat atau yang aktif atau pernah aktif mengelola kegiatan keislaman atau masjid. SD Al Muttaqin mempunyai prinsip bahwa semua guru adalah guru PAI, semua itu dalam rangka mewujudkan terbentuknya akhlak anak didik yang berdasarkan ajaran Islam. Semua guru yang mengajar harus bekerja dengan keikhlasan dan penuh kesabaran. Selain melakukan rekrutmen guru yang selektif, untuk menghasilkan guru yang berkualitas yayasan menaungi SD Al Muttaqin, melakukan ujian bagi guru setiap tahunnya secara berkelanjutan. Ujian bagi guru tersebut menekankan pada pemahaman keagamaan guru serta pengamalannya terutama berkaitan dengan baca tulis Alquran untuk selanjutnya di berikan buku laporan penilaiannya.

Semua itu sesuai dengan syarat menjadi guru yang disampaikan oleh Daradjat (2014) mengklasifikasikan syarat-syarat menjadi seorang guru sebagai berikut; pertama, takwa kepada Allah Swt. Guru sesuai dengan tujuan ilmu pendidikan Islam tidak mungkin mendidik anak agar bertakwa kepada Allah jika dia sendiri tidak takwa kepada-Nya. Sebab ia adalah teladan bagi muridnya sebagaimana guru mampu memberi teladan baik kepada muridmuridnya sejauh itu pulalah ia diperkirakan akan mendidik mereka agar menjadi generasi penerus bangsa yang baik dan mulia. Kedua, berilmu. Ijazah bukan semata-mata secarik kertas, tetapi suatu bukti bahwa pemiliknya mempunyai ilmu pengetahuan dan kesanggupan tertentu yang diperlukannya untuk suatu jabatan. Gurupun harus mempunyai ijazah supaya ia dibolehkan mengajar. Kecuali dalam keadaan darurat, misalkan jumlah murid sangat meningkat sedangkan jumlah guru jauh daripada mencukupi, maka terpaksa menyimpang untuk sementara, yakni menerima guru yang belum berijazah. Tetapi dalam keadaan normal ada patokan bahwa semakin tinggi pendidikan guru makin baik mutu pendidikan dan pada gilirannya makin tinggi pula derajat masyarakat. Ketiga, sehat jasmani. Kesehatan jasmani kerapkali dijadikan salah syarat bagi mereka yang melamar untuk menjadi guru. Guru yang mengidap penyakit menular umpanya sangat membahayakan kesehatan anak-anak. Di samping itu, guru yang sering sakit-sakitan tidak akan bergairah mengajar. Keempat, berkelakuan baik. Budi pekerti guru sangatlah penting dalam pendidikan watak muridnya. Guru harus menjadi suri teladan yang baik, karena seagala sesuayunya akan ditiru oleh anak didiknya. Dari mulai gaya bicara, pakaian, cara berjalan dan lain sebagainya.

Lebih lanjut selain syarat-syarat tersebut menurut Daradjat (2014) seorang guru harus memiliki kahlak mulia. Akhlak yang sesuai dengan ajaran Islam, seperti dicontohkan oleh Nabi Muhammad Saw. Diantara akhlak guru tersebut adalah; pertama mencitai jabatannya sebagai guru. Profesi guru merupakan profesi yang sangat mulia sehingga tidak ada alasan untuk tidak mencintai profesi tersebut. Namun dalam kasus tertentu ada kalanya seseorang menjadi guru karena keterpaksaan. Dalam keadaan bagaimanapun seorang guru harus berusaha mencintai pekerjaanya. Kedua, bersikap adil terhadap semua muridnya. Seorang guru harus memperlakukan semua anak didiknya dengan sama tidak melihat latar belakang keluarganya. Tidak membedaan berdasarkan jenis kelaminnya. Ketiga, Berlaku sabar dan tenang. Seorang guru harus memiliki kemampuan memngendailkan emosinya. Stabil dari segi psikologis akan bersikap tenang dan bijaksana dalam menghadapi anaknya didik. Keempat, Guru harus berwibawa. Dalam pendidikan kewibawaan adalah syarat mutlak. Mendidik ialah membimbing anak dalam perkembangannya ke arah tujuan pendidikan. Bimbingan atau pendidikan hanya mungkin bila ada kepatuhan dari pihak anak dan kepatuhan diperoleh bila pendidik mempunyai kewibawaan. Kewibawaan sejati diperoleh guru berdasarkan kepribadiannya sendiri. Kelima, guru harus gembira. Guru yang selalau riang gembira akan sangat berpengaruh terhadap suasana belajar di kelas. Sehingga pembelajaran 
akan lebih menyenangkan. Keenam, guru harus bersifat manusiawi. Guru adalah manusia yang tidak lepas dari kekurangan dan cacat, ia bukan manusia sempurna. Ia memberikan hukuman yang adil dan suka memaafkan apabila anak insaf dari kesalahannya. Kedelapan, bekerja sama dengan guru-guru lainPertalian dan kerja sama yang erat antara guru-guru lebih berharga daripada gedung yang molek dan alat-alat yang cukup. Sebab apabila guru-guru saling bertentangan, anak-anak akan bingung dan tidak tahu apa yang dibolehkan dan apa yang dilarang. Oleh karena itu kerja sama antara guru-guru sangat penting. Kesembilan, bekerja sama dengan masyarakat. Guru harus mempunyai pandangan luas. Ia harus bergaul dengan segala golongan manusia dan secara aktif berperan serta dalam masyarakat supaya sekolah tidak terpencil. Sekolah hanya dapat berdiri ditengah-tengah masyaraakat apabila guru rajin bergaul, suka mengunjungi orang tua murid-murid.

Dalam setiap kesempatan guru di SD Al Muttaqin harus menekankan akan pentingnya berakhlak yang baik. Oleh karena diharuskan pada semua guru dalam setiap kegiatan pembelajaran agar memberikan nasihat serta motivasi untuk selalu berbuat baik pada sesama, pada orang tua, guru di mana pun dan kapan pun serta tidak pernah meninggalkan perintah Allah swt. SD Al Muttaqin mengatur atau melakukan penjadwalan berkaitan dengan materi tema pesan serta waktunya bagi setiap guru. Pertama pada saat pagi hari ketika pembelajaran akan dimulai pesan yang disampaikan di antaranya adalah menanyakan salat subuh, memberikan motivasi untuk belajar dengan baik, melaksanakan tadarus, membaca doa-doa harian serta menghafalkan bacaan salat. Kedua pada saat menjelang istirahat pertama pesan yang disampaikan adalah menganjurkan salat duha, memberikan peringatan untuk tidak bermain bola, mengarahkan agar membaca di perpustakaan, melarang untuk keluar lingkungan sekolah.

Ketiga menjelang istirahat kedua, guru langsung mengajak siswa untuk langsung berwudu, selanjutnya guru langsung mengajak masuk ke masjid kemudian salat. Pada saat di dalam masjid guru mengarahkan siswa untuk tidak mengobrol, siswa diarahkan untuk duduk dengan rapi kemudian berzikir. Setelah selesai melaksanakan salat siswa langsung menuju ke ruang makan kemudian berdoa untuk makan. Keempat menjelang salat asar guru mengarahkan siswa untuk langsung wudu, duduk dengan rapi di dalam masjid, berzikir dan tidak mengobrol, selanjutnya melaksanakan salat sunat. Guru melarang siswa untuk pulang apabila belum melaksanakan salat asar berjamaah. Kelima saat sebelum salat berjamaah guru memberikan nasihat kepada siswa tentang beberapa hal yaitu mengingatkan untuk salat di rumah secara berjamaah, membaca Alquran setelah selesai salat, menyiapkan buku pelajaran sebelum tidur. Kemudian mengingatkan siswa untuk membaca buku pelajaran, mengerjakan tugas dan PR yang diberikan guru, serta mengingatkan agar salat subuh jangan sampai kesiangan.

Nasihat-nasihat yang baik penting diberikan kepada siswa secara kontinu dan konsisten agar siswa selalu mengingat akan halhal yang sangat penting. Siswa akan terlena dengan berbagai kesibukannya apabila tidak selalu diingatkan. Nasihat yang sering didengarkan siswa akan selalu terngiang dan teringat, dengan harapan di mana pun dan kapan pun siswa akan menjalankan nasihat yang diberikan guru. Selain nasihat-nasihat yang disampaikan guru kegiatan yang paling penting adalah pelaksanaan dari apa yang disampaikan.

Salat berjamaah merupakan kegiatan wajib yang harus diikuti setiap komponen sekolah, baik guru, siswa ataupun pegawai lainnya. Tujuannya tidak lain adalah untuk menanamkan pembiasaan sejak dini akan pentingnya salat berjamaah. Adapun kegiatan salat berjamaah yang dilakukan di SD Al Muttaqin di antaranya adalah. Pertama adalah kegiatan salat duha berjamaah. Kegiatan ini dilaksanakan pada saat istirahat pertama yaitu pada pukul 10.10. Semua guru memberikan teladan dalam pelaksanaannya serta mengarahkan agar seluruh siswa mengikuti salat duha secara bersama-sama di masjid sekolah dan sebagian lagi di aula sekolah. Kegiatan ini rutin dilakukan sebagai pendidikan pembiasaan bagi peserta didik. Selain melaksanakan salat duha sebelumnya juga dilakukan zikir dan doa terlebih dahulu, tujuannya agar siswa dapat mempraktikkan hafal doa-doa harian yang diajarkan di dalam kelas. 
Kedua adalah kegiatan salat fardu secara berjamaah. Kegiatan ini merupakan kegiatan yang wajib diikuti oleh semua komponen sekolah baik, guru, tata usaha ataupun personil lainnya. Salat fardu yang dilaksanakan adalah salat zuhur dan asar. Semua kegiatan di sekolah harus berhenti ketika sudah terdengar azan zuhur dan asar, tidak boleh lagi ada kegiatan pembelajaran, semua siswa diperintahkan untuk segera mengambil air wudu untuk segera menuju ke masjid. Faktor keteladan dari seorang guru menjadi penentu keberhasilan pembelajaran PAI di sekolah. Keteladanan guru di SD Al Muttaqin sangat diutamakan, sehingga setiap saat guru harus selalu menjadi contoh bagi siswanya.

Metode pembiasaan merupakan metode yang paling tepat bagi internalisasi nilai-nilai keagamaan dalam kehidupan sehari-hari, serta metode yang sangat cocok untuk pembentukan karakter anak didik. Seperti apa yang disampaikan Akhwan (2011) bahwa dalam pembentukan karakter dibutuhkan metode pendidikan khusus, di antara metode yang tepat adalah metode keteladanan, pembiasaan serta metode pujian dan hukuman.

\section{Model Evaluasi Hidden Curriculum di SD Al Muttaqin}

Arikunto (2003) menyatakan evaluasi pendidikan adalah kegiatan menilai yang terjadi dalam kegiatan pendidikan. Tujuan evaluasi dalam proses belajar mengajar adalah untuk mendapatkan informasi akurat mengenai tingkat pencapaian tujuan instruksional oleh siswa sehingga dapat diupayakan tindak lanjutnya. Sementara itu Sudijono (1996) menjelaskan evaluasi pendidikan secara umum evaluasi sebagai suatu tindakan atau proses setidak-tidaknya memiliki tiga macam fungsi pokok, yaitu mengukur kemajuan, menunjang penyusunan, dan memperbaiki atau melakukan penyempurnaan kembali.

Dalam pembelajaran PAI evaluasi pendidikan harus dilaksanakan secara proporsional antara berbagai aspek, baik kognitif, afektif dan psikomotorik. Evaluasi pembelajaran PAI tidak boleh hanya pada pemahaman atau pengetahuan ilmu-ilmu keagamaannya saja tetapi aspek perilaku sikap serta pelaksanaan ibadah harian juga harus menjadi perhatian guru. Oleh karena itu pengukuran hasil belajar untuk pendidikan agama Islam, tidak boleh hanya aspek kuantitatif, berupa angka-angka simbol nilai, tetapi juga harus dilakukan evaluasi secara kualitatif, melalui berbagai metode dan cara. Pendidikan Islam harus mengembangkan evaluasi tersendiri yang tidak hanya mengevaluasi aspek kognitif atau pemahaman tentang materi PAI. Evaluasi yang dapat dikembangkan untuk menilai sikap keberagamaan siswa dapat dilakukan dengan pengamatan, praktik serta portofolio. Untuk menghasilkan hasil tes yang menyeluruh sekolah harus bekerja sama dengan orang tua untuk membuat portofolio yang menyeluruh.

SD Al Muttaqin sebagai sekolah yang mengutamakan aspek pengembangan akhlak siswa, mencoba melakukan evaluasi pembelajaran PAI siswa dengan berbagai cara. Engkos Kosasih sebagai kepala sekolah mengharuskan kepada setiap guru untuk membuat berbagai alternatif tes terhadap siswa. Seperti sekolah umum lainnya SD Al Muttaqin juga menerapkan beberapa ujian yaitu ulangan harian, ujian tengah semester, ujian akhir semester serta ujian sekolah dan ujian nasional untuk kelas enam. Dari beberapa ujian tersebut tentunya selain ujian nasional kepala sekolah mengharapkan adanya instrumen ujian yang bervariasi tidak hanya sekedar pilihan ganda dan esai, tetapi guru diwajibkan membuat instrumen tes dalam bentuk lain. Tujuannya tidak lain untuk mendapatkan hasil ujian yang komprehensif dan juga mengurangi kejenuhan siswa terhadap ujian. Ujian-ujian tersebut biasanya dilakukan untuk mengevaluasi ranah kognitif siswa.

Selain ujian-ujian tersebut, SD Al Muttaqin juga menerapkan model evaluasi tersendiri yaitu model evaluasi untuk mengetahui aktivitas sehari-hari siswa terutama dalam hal pengamalan keagamaan. Metode ini berusaha untuk mengevaluasi ranah afektif siswa SD Al Muttaqin. Seperti yang dikatakan Anderson (2010) ada dua metode yang dapat digunakan untuk mengukur ranah afektif, yaitu metode observasi dan metode laporan-diri. Penggunaan metode observasi berdasarkan pada asumsi bahwa karakteristik afektif dapat dilihat dari perilaku atau perbuatan yang 
ditampilkan, reaksi psikologi, atau keduanya. Metode laporan diri berasumsi bahwa yang mengetahui keadaan afektif seseorang adalah dirinya sendiri. Namun, hal ini menuntut kejujuran dalam mengungkap karakteristik afektif diri sendiri.

Model ujian yang coba dikembangkan SD Al Muttaqin untuk menilai ranah afektif siswa adalah dengan melibatkan orang tua di rumah untuk selalu memantau aktivitas siswa ketika di rumah. Model evaluasi yang diterapkan adalah dengan menerbitkan buku penghubung antara guru dengan orang tua. Buku penghubung tersebut merupakan sarana komunikasi antara guru dengan orang tua. Dengan buku penghubung tersebut guru dapat mengetahui kegiatan siswa di rumah, sebaliknya melalui buku tersebut juga orang tua dapat mengetahui aktivitas siswa di sekolah. Buku penghubung yang merupakan evaluasi siswa berisi tentang aktivitas siswa ketika berada di sekolah. Isi buku yang harus diisi guru adalah kedatangan siswa ke sekolah tepat atau terlambat, berpakaian rapai, lengkap atau tidak, peralatan sekolah, mengerjakan PR atau tidak Kemudian ketenangan dan disiplin di kelas, ketepatan masuk setelah istirahat, ketertiban dalam salat, ketertiban dalam makan dan perilaku sosial siswa di sekolah. Semua itu bertujuan agar perilaku siswa di sekolah dapat diketahui oleh orang tua di rumah.

Sedangkan yang harus diisi oleh orang tua ketika siswa berada di rumah adalah ibadah salat siswa dan tadarus Alquran. Kalau anaknya melaksanakan salat maka orang tua mencentang "ya" pada buku penghubung tersebut, dan apabila tidak melaksanakan maka yang dicentang adalah "tidak". Sedangkan untuk tadarus siswa orang tua mencatatkan surat dan ayatnya. Selain itu dalam buku penghubung tersebut tersedia kolom informasi siswa yang disediakan untuk orang tua yang akan menuangkan informasi yang dianggap penting kepada guru berkaitan dengan anaknya, misalnya masalah belajar anak, keluhan anak di sekolah serta aktivitas siswa pada hari libur dan yang lainnya yang dianggap penting. Selain itu di dalam buku ini juga orang tua boleh mengajukan kritik dan saran kepada guru dalam melaksanakan pembelajaran dikelas serta memberikan masukan tentang kelebihan dan kekurangan perkembangan belajar anaknya. Walaupun tersedia berbagai jenis media komunikasi, tetapi buku penghubung merupakan media resmi komunikasi antara guru dan orang tua siswa.

Buku penghubung tersebut diisi oleh orang tua harus dengan sejujur-jujurnya berdasarkan fakta yang ada, karena sekolah mengharapkan data apa adanya untuk selanjutnya sebagai bahan evaluasi siswa akan kekurangan-kekurangan untuk dilakukan perbaikan. Sedangkan apabila data yang diberikan oleh orang tua tidak berdasarkan fakta maka akibatnya akan menyesatkan anaknya sendiri, karena guru tidak bisa memberikan arahan dan bimbingan dalam rangka perbaikan atas kekurangan yang dihadapi siswa. Sekolah mengharapkan kebenaran data apa adanya karena tidak berkaitan dengan benar atau salah tetapi merupakan sebuah proses dari pendidikan. Dengan adanya buku penghubung maka komponen sekolah semuanya bekerja sama untuk memberikan pendidikan pada peserta didik, sehingga dengan begitu tujuan pendidikan akan mudah tercapai.

Dengan adanya buku penghubung orang tua merasa terbantu untuk mengetahui perkembangan harian belajar anaknya, apakah aktif atau tidak. Selain itu orang tua bisa ikut memberikan masukan kepada sekolah bimbingan seperti apa yang dibutuhkan bagi anaknya. Bagi siswa dengan adanya buku pembimbing siswa akan merasa di awasi setiap saat segala tingkah lakunya. Pada mulanya siswa pasti merasa terpaksa dan tidak nyaman dengan adanya laporan harian kegiatan di rumahnya, tetapi walaupun pada awalnya merasa terpaksa tetapi lama kelamaan menjadi terbiasa untuk selalu berbuat baik, dan melaksanakan segala ibadah yang telah ditentukan.

Dengan adanya evaluasi dengan buku penghubung menurut orang tua murid, manfaat yang dirasakan adalah anaknya selalu tepat waktu dalam melaksanakan ibadah salat, serta salatnya pun selalu minta berjamaah. Apabila sekali saja anak lupa tidak melaksanakan salat sementara orang tuanya tidak mengingatkan maka ia akan marah besar. Semua itu merupakan bentuk kebanggaan bagi orang 
tuanya, selain tentunya sikap dan perilakunya lebih baik lagi.

Untuk melaksanakan pendidikan pembiasaan di SD Al Muttaqin dalam beberapa hal pihak sekolah menerapkan pendidikan pemaksaan terutama yang berkaitan dengan ibadah wajib umat Islam, seperti salat, berakhlak baik, membaca Alquran, menghafal dan lain sebagainya. Dengan sedikit pemaksaan maka kebiasaan-kebiasaan baik lama kelamaan akan diterima siswa. Usia sekolah siswa belum memahami akan manfaat dan pentingnya apa yang diajarkan, oleh karena itu dalam beberapa hal perlu adanya pemaksaan. Seperti yang disampaikan oleh Engkos Kosasih kepala SD Al Muttaqin bahwa pendidikan itu perlu dipaksa. Pada mulanya siswa merasa terpaksa, tetapi kami yakin dalam beberapa waktu ke depan mereka akan terbiasa, bisa karena terbiasa, lebih lanjut dikatakan melalui pembiasaanpembiasaan itu pun, pihaknya optimistis jika gejolak-gejolak sosial yang mengarah pada upaya perusakan karakter generasi bangsa akan terproteksi.

Berbagai ikhtiar terus dilakukan untuk memperbaiki akhlak anak didik, sebagai penerus bangsa, hanya melalui pendidikanlah satu-satunya jalan terbaik yang dapat memperbaiki berbagai krisis dan problematik karakter bangsa. SD Al Muttaqin sedikit banyak telah berkontribusi dalam menjaga moral anak sejak dini, dan pendidikan agama Islam sebagai ujung tombak dari semua proses pendidikan di SD Al Muttaqin.

\section{PENUTUP}

Penelitian ini menunjukan bahwa SD al Muttaqin telah berhasil memadukan kurikulum tertulis dan kurikulum tersembunyi, melalui pembelajaran PAI. Implementasi kurikulum tersembunyi terwujud dalam kegiatan ekstrakurikuler dan pengembangan diri siswa. Untuk menunjang implementasi kurikulum tersembunyi guru menjadi kunci utama, karena semua guru berperan sebagai guru agama. Proses rekruitmen guru dilakukan secara selektif dengan kriteria yang memenuhi syarat untuk mengajarkan agama dan menjadi teladan bagi siswa. Evaluasi pendidikan agama dilakukan secara terintegratif oleh guru, siswa sendiri dan oleh orang tua siswa melalui buku penghubung.

Berdasarkan temuan penelitian, SD al Muttaqin sebagai sekolah swasta Islam telah menerapkan kurikulum yang memadukan antara tertulis dan kurikulum tersembunyi, sehingga menghasilkan pembelajaran yang efektif. Hal tersebut terbukti dari prestasi bidang PAI selalau unggul dibanding dengan sekolah lain yang ada di kota tasikmalaya.

\section{DAFTAR PUSTAKA}

Abdullah, A. (2007) 'Kurikulum Pendidikan di Indonesia Sepanjang Sejarah (Suatu Tinjauan Kritis Filosofis)'. Jurnal Pendidikan dan Kebudayaan,. 66 (345).

Ali, M dan R. Ibrahim, (2012) Teori Evaluasi Pendidikan, dalam Ali, M (ed) Ilmu dan Aplikasi Pendidikan. Jakarta: Grasindo.

Akhwan, M, (2011) Pendidikan Karakter, Konsep dan Implementasinya dalam Pembelajaran di Sekolah/Madrasah, Makalah disampaikan dalam diskusi dosen Fakultas Ilmu Agama Islam UII, tanggal 2 Nopember 2011.

Arikunto, S. (2003) Dasar-Dasar Evaluasi Pendidikan. Jakarta: Bumi Aksara.

Anderson, L. W dan David R. Krathwohl. (2010). Terjemahan. Kerangka Landasan Untuk Pembelajaran, Pengajaran, dan Asesmen. Revisi Taksonomi Bloom. Yogyakarta: Pustaka Pelajar.

Cresswell, J. W. (2010) Research Design: Pendekatan Kualitatif, Kuantitatif dan Mixed, Edisi Ketiga. Yogyakarta: Pustaka Pelajar.

Darajad, D. (2011) Ilmu Pendidikan Islam. Jakarta: Rajawali Pers.

Djamaluddin (2008) Pendidikan Agama Islam dan Konflik Sosial, KREATIF Jurnal Studi Pendidikan, 4(7).

Fauzi, M. (2008) Telaah Filosofis Kurikulum Pendidikan Islam Di Sekolah Umum. Jakarta: UIN Syarif Hidayatullah. 
Haedari, A. (2012) Kembangkan Akhlak Siswa Melalui Ekstrakurikuler PAI. Tersedia pada

http://pendis.kemenag.go.id/kerangka/p ais.htm (Diakses 19 November 2012).

Hasan, S. (2010) Ilmu dan Aplikasi Pendidikan. Jakarta: Grasindo.

Haryanto (2010) Kurikulum Integratif Menuju Pendidikan Agama Islam Model Terpadu. Jakarta: UIN Syarif Hidayatullah.

Hidayat, K. (2012) Membangun Kultur Sekolah. Tersedia pada http://www.uinjkt.ac.id, (diakses pada 04 November 2012).

Indriyanto, B. (2012) Mengapresiasi Profesi Guru di Hari Guru. Tersedia di www.kemdikbud.go.id (diakses 19 November 2019).

Iskandar (2008) Metodelogi Penelitian Pendidikan dan sosial, Kuantitatif dan Kualitatif. Jakarta: GP Pers.

Klein, M. F. (1986) Curriculum Reform in the Elementary School: Creating Your Own Agenda. New York and London: Teachers College Columbia University.

Koesoema, D. (2012) Pendidikan Karakter Utuh dan Menyeluruh. Yogyakarta: Kanisius.

Lickona, T. (2012) Educating For Character; Mendidik Untuk Membentuk Karakter, (terj) Uyu Wahyudin. Jakarta: Bumi Aksara.

Mardapi, D. (2012) Penilaian Pendidikan Karakter, tersedia pada http://staff.uny.ac.id/sites/default/files/t mp/Penilaian_karakter.pdf, (diakses 25 November 2012).

Masykuri, R. (2008) Pengembangan Model Kurikulum dan Pembelajaran Inkuiri dalam Pendidikan Agama Islam di SLTP. Bandung: Universitas Pendidikan Indonesia.

Mukhlis, F. (2012) Ektrakurikuler Untuk Pembinaan Karakter Siswa. Tersedia pada http://pasca.uin-malang.ac.id, (diakses 2 Desemeber 2012).

Akhwan, M. (2011) Pendidikan Karakter, Konsep dan Implementasinya dalam Pembelajaran di Sekolah/Madrasah, UII (ed) Yogyakarta: FIAI UII .

Noor, R. M. (2012) The Hidden Curriculum: Membangun Karakter Melalui Kegiatan Ekstrakurikuler. Yogyakarta: Insan Madani.

Murni, W. (2012). Kurikulum Tersembunyi. Tersedia pada http://tarbiyah.uinmala ng.ac.id/Artikel-12-kurikulum-tersemb unyi.html (diakses 30 Oktober 2012)

Nata, A. (2005). Filsafat Pendidikan Islam. Jakarta: Logos Wacana.

Semiawan, C. (2012). Metodologi Penelitian Kualitatif .Jakarta: Grasindo .

Sanjaya, W. (2010). Kurikulum dan Pembelajaran. Jakarta: Kencana Prenda Media Group.

Sudharto. (2012). Pengaruh Budaya Organisasi Sekolah, Pengalaman Kerja, Dan Kompensasi Terhadap Kepuasan, Motivasi Kerja, Dan Kinerja Kepala SMA Se Eks Karesidenan Semarang. Tersedia pada staff.uny.ac.id (diakses pada 04 November 2012).

Sugiyono. (2014). Metode Penelitian Kuantitatif, Kualitatif, dan Kombinasi (Mixed Method). Bandung: Alfabeta.

Sudijono, A. (1996). Pengantar Evaluasi Pendidikan. Jakarta: Raja Grafindo Persada.

Sukmadinata, N.S. (2007). Pengembangan Kurikulum Teori dan Praktek. Bandung: Remaja Rosda Karya.

Yuksel, S. (2005). "Kohlberg and Hidden Curriculum in Moral Education: An Opportunity for Students' Acquisition of Moral Valuesin the New Turkish Primary Education Curriculum.". Journal Of Educational Sciences: Theory \& Practice, 30(3).

Zamroni. (2003). Paradigma Pendidikan Masa Depan. Jakarta: Bigraf Publishing. 
